\title{
Fumigation of Fruit with Short-Chain Organic Acids to Reduce the Potential of Postharvest Decay
}

\author{
P. L. Sholberg, Agriculture and Agri-Food Canada, Pacific Agri-Food Research Centre, Summerland, B.C. Canada
}

\begin{abstract}
Sholberg, P. L. 1998. Fumigation of fruit with short-chain organic acids to reduce the potential of postharvest decay. Plant Dis. 82:689-693.

Vapors of acetic $(1.9$ or $2.5 \mu \mathrm{l} /$ liter $)$, formic $(1.2 \mu \mathrm{l} /$ liter $)$, and propionic $(2.5 \mu \mathrm{l} /$ liter $)$ acids were tested for postharvest decay control on 8 cherry, 14 pome, and 3 citrus fruit cultivars. Surfacesterilized fruit were inoculated with known fungal pathogens by drying $20-\mu l$ drops of spore suspension on marked locations on each fruit, placing at $10^{\circ} \mathrm{C}$ to equilibrate for approximately $24 \mathrm{~h}$, and fumigating by evaporating the above acids in 12.7-liter airtight fumigation chambers for $30 \mathrm{~min}$. Immediately after fumigation, the fruit were removed, aerated, aseptically injured, and placed at $20^{\circ} \mathrm{C}$ until decay occurred. All three fumigants controlled Monilinia fructicola, Penicillium expansum, and Rhizopus stolonifer on cherry. Formic acid increased fruit pitting on six of eight cultivars and was the only organic acid to increase blackening of cherry stems when compared to the control. Decay of pome fruit caused by P. expansum was reduced from $98 \%$ to 16,4 , or $8 \%$ by acetic, formic, and propionic acids, respectively, without injury to the fruit. Decay of citrus fruit by $P$. digitatum was reduced from 86 to $11 \%$ by all three acids, although browning of the fruit peel was observed on grapefruit and oranges fumigated with formic acid.
\end{abstract}

Additional keywords: apple, stone fruit

Short-chain organic acids, such as acetic and propionic acids, are commonly used by food manufacturers as antimicrobial preservatives or acidulants in a variety of food products (2). Formic acid, containing only one carbon, is the smallest short-chain organic acid in this group; but due to its toxicity, it has found limited use in foods, although it is still used in many industrial processes. Very little pure acetic acid is used in foods, but as the principal component of vinegars, more than 100,000 tons are produced annually in the United States for food (9). The use of propionic acid and propionates has been directed primarily against molds, although some yeasts and bacteria, particularly gram-negative strains, may also be inhibited (2). Propionate has been estimated to account for approximately $75 \%$ of all chemical preservatives consumed, primarily because of its extensive use in bread and bakery products (21). Acetic, formic, and propionic acids have melting points of 17,8 , and $-24^{\circ} \mathrm{C}$, boiling points of 118,100 , and $141^{\circ} \mathrm{C}$, and vapor pressures of 11.8, 35.0, and $2.4 \mathrm{~mm} \mathrm{Hg}$ at

Corresponding author: P. L. Sholberg

E-mail: Sholbergp@em.agr.ca

Agriculture and Agri-Food Canada Contribution 1038.

Accepted for publication 11 February 1998.

Publication no. D-1998-0330-02R

(C) 1998 Department of Agriculture and Agri-

Food, Government of Canada $20^{\circ} \mathrm{C}$, respectively, making them relatively volatile liquids.

Recently, Sholberg and Gaunce (17) found that vaporized acetic acid was extremely effective for killing spores of decay-causing fungi. Fumigation with 2.0 or $4.0 \mathrm{mg}$ of acetic acid per liter of air prevented apples, grapes, kiwifruit, pears, and tomatoes inoculated with Botrytis cinerea and apples, oranges, and pears inoculated with Penicillium spp. from decaying by killing surface-borne conidia prior to injury. In subsequent experiments, acetic acid was an effective postharvest fumigant on stone fruit, controlling decay by Monilinia fructicola (G. Wint.) Honey and Rhizopus stolonifer (Ehrenb.:Fr.) Vuill. at concentrations as low as $1.4 \mathrm{mg}$ of acetic acid per liter (18). On table grapes, fumigation with $8.0 \mathrm{mg}$ of acetic acid per liter controlled decay in each of 3 years as effectively as sulfur dioxide fumigations applied at commercial rates (19). In combination with modified-atmosphere packaging, acetic acid fumigation controlled decay on grapes for 74 days at $0^{\circ} \mathrm{C}$ and on fresh strawberries for 14 days at $5^{\circ} \mathrm{C}$ (13).

Since acetic acid was effective against a wide range of postharvest pathogens on a number of crops, there was interest at our Research Centre in determining if the other closely related short-chain organic acids, formic and propionic, would have similar effects on spores of various postharvest pathogens on citrus fruit, pome fruit, and stone fruit. Research with all three acids at concentrations effective for controlling decay would also provide evidence that they all used the same mode of action because they have very similar chemical properties. It was also important to compare the phytotoxicity of all three acids on a wide range of fruit crops and various cultivars within each crop to assess if they would have any potential for future commercial development. A preliminary report of this research has been published (16).

\section{MATERIALS AND METHODS}

Fruit. Cherries of eight different cultivars (Bing, Lambert, Lapin, Stella, Sweetheart, Sylvia, Van, and 5J98 White) that were being assessed for quality by Agriculture and Agri-Food Canada at the $\mathrm{Pa}$ cific Agri-Food Research Centre (PARC), Summerland, British Columbia (BC), were used in fumigation trials. The cherries were harvested at commercial maturity during the summer of 1995 and were stored at $1{ }^{\circ} \mathrm{C}$ for up to 2 weeks before being used. Similarly, following the end of cherry harvest, 4 apricot (Blenheim, Skaha, Sungold, and Tilton), 2 peach (Glohaven and Harbrite), 1 nectarine (Harblaze), 13 apple (Empire, Frumose di Vionesti, Gala, Gloster, Golden Delicious, Granny Smith, Liberty, Jonagold, McIntosh, Newtown, Red Delicious, Shamrock, and Spartan), and 1 pear cultivar (Anjou) were harvested at commercial maturity for use in this study. Fungicide-free navel oranges and grapefruit and commercially grown lemons were purchased from local merchants. Stone fruit were surface-sterilized with $0.5 \%$ sodium hypochlorite solution for 60 $\mathrm{s}$, rinsed in sterile water, and dried. Pome and citrus fruit were surface-sterilized by wiping each fruit with $95 \%$ ethanol.

Inoculum. Isolates used in these experiments were originally isolated from infected fruit $(17,18)$. Cherries were inoculated with $M$. fructicola, $R$. stolonifer, and Penicillium expansum Link, while other apricots, peaches, and nectarines were inoculated with $M$. fructicola and $R$. stolonifer. Apples and pears were inoculated with $P$. expansum and citrus fruit with $P$. digitatum (Pers.:Fr.) Sacc. The cultures were maintained on potato dextrose agar (PDA) slants at $2^{\circ} \mathrm{C}$ until needed. Isolates were grown on PDA for 1 to 2 weeks at 20 to $23^{\circ} \mathrm{C}$. Spores were harvested by washing a sporulating culture with 5 to $10 \mathrm{ml}$ of sterile distilled water into a screw cap test tube. Contents were thoroughly mixed prior to counting with a hemacytometer and adjusting to $10^{6}$ conidia per $\mathrm{ml}$. The adjusted suspension was dispensed in 1-ml 
aliquots into 2-ml cryovials, frozen, and stored at approximately $-20^{\circ} \mathrm{C}$. Spore suspensions were thawed for 10 to $15 \mathrm{~min}$, used for inoculation of individual fruits, and returned to the freezer until needed again. Cherries were inoculated in the laminar flowhood by inscribing an approximately $1-\mathrm{cm}$-diameter circle with a black marking pen on the cherry surface and placing a $20-\mu$ ldrop of spore suspen- sion within the circle, where the drop was allowed to dry. Similarly, apricots were inoculated with 3 drops, and peaches, nectarines, pome, and citrus fruit were inoculated with 4 drops evenly distributed around the suture end of each fruit. Once the drops had dried, the fruit was placed in a $10 \pm 0.2^{\circ} \mathrm{C}$ humidified ( 95 to $100 \%$ relative humidity) compartment (Conviron, Winnipeg, Canada) overnight.

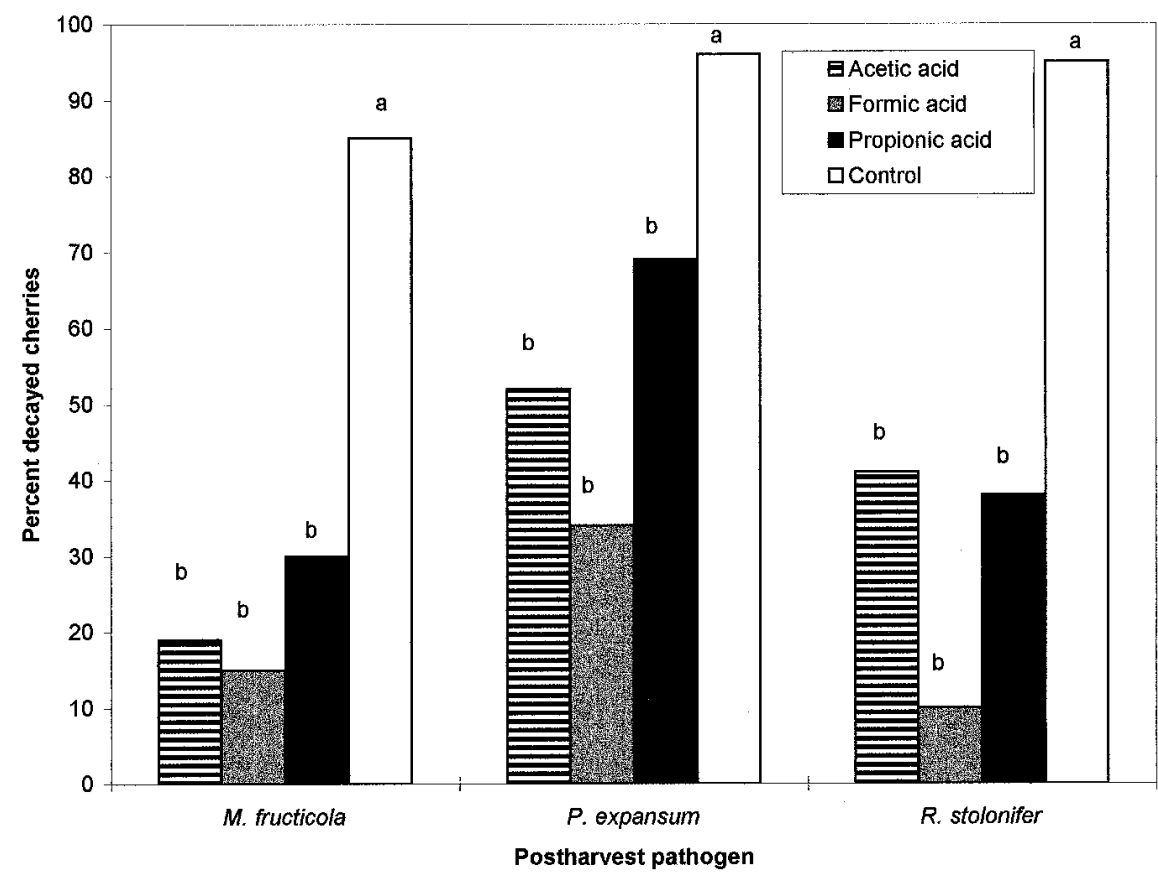

Fig. 1. Decayed cherries after inoculation with $10^{6}$ conidia of Monilinia fructicola, Penicillium expansum, or Rhizopus stolonifer per $\mathrm{ml}$ and fumigation with $1.3 \mu \mathrm{l}$ of formic acid, $1.9 \mu \mathrm{l}$ of acetic acid, or $2.5 \mu \mathrm{l}$ of propionic acid per liter. For each postharvest pathogen, different letters above bars indicate significant $(P \leq 0.002)$ differences among acids of arcsine-transformed data as determined by the least significant difference test.

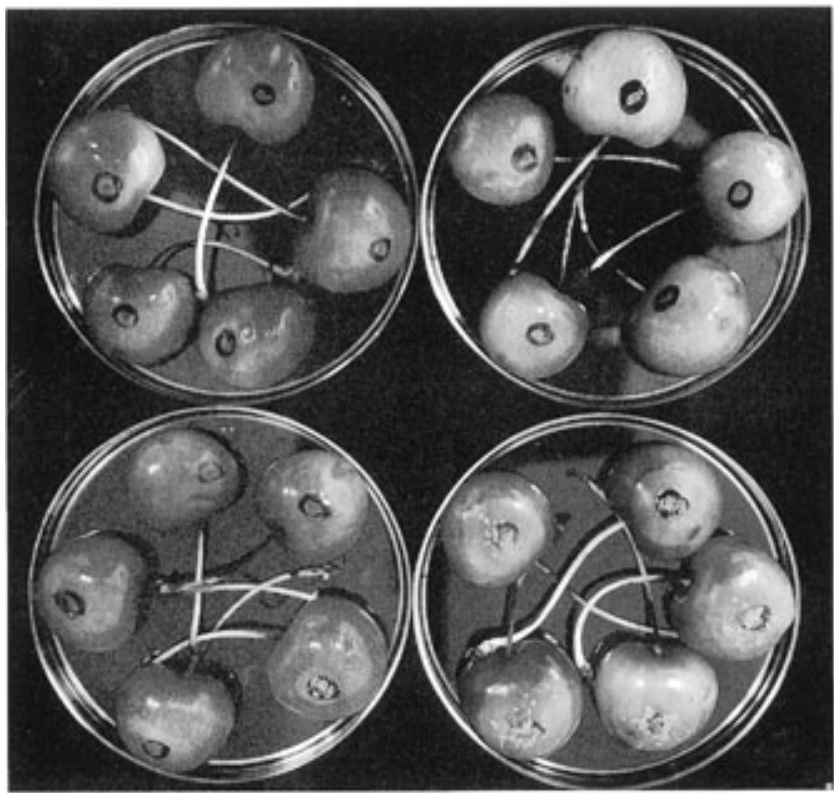

Fig. 2. Selection 5J98 white cherries inoculated with Monilinia fructicola and fumigated with formic, acetic, or propionic acids. Top left $=1.9 \mu \mathrm{l}$ of acetic acid per liter; top right $=1.3 \mu \mathrm{l}$ of formic acid per liter; bottom left $=2.5 \mu \mathrm{l}$ of propionic acid per liter; and bottom right $=$ nonfumigated control. Note the sporulation and decay by M. fructicola on the nonfumigated control fruit.
Fumigation. Fruit were fumigated at $10^{\circ} \mathrm{C}$ with reagent grade glacial acetic $(99.99 \%)$, propionic (99 to $100 \%$ ), and formic (98 to $100 \%$ ) acids in three 12.7 liter chambers made from $11-\mathrm{kg}$-capacity tin cans fitted with a $0.6-\mathrm{A}, 115-\mathrm{V}$ circulation fan attached to the lid as previously described (17). Each chamber was designated for the use of a particular acid to avoid acid contamination from one fumigation to the next and left at $10^{\circ} \mathrm{C}$ until the end of the study. Following the procedure described previously for acetic acid (18), four fruit (citrus, pome, or stone fruit) or 15 cherries per acid were fumigated within airtight 12.7-liter chambers for $30 \mathrm{~min}$, with formic acid at $1.3 \mu \mathrm{l} /$ liter, acetic acid at $1.9 \mu \mathrm{l} /$ liter, and propionic acid at 2.5 $\mu \mathrm{l} /$ liter. The chambers were removed from the room and opened in a fume hood to allow any concentrated fumes to escape.

Evaluation. After aeration for 20 to 30 min, the fruit were placed in a laminar flow hood and aseptically injured with a glass rod (2 mm diameter) within the inscribed circles to a depth of approximately $5 \mathrm{~mm}$ and incubated in a $20 \pm 0.2^{\circ} \mathrm{C} \mathrm{com}$ partment (Conviron) for 3 to 6 days, depending on occurrence of significant decay on the control fruit.

Fumigated fruit were inspected for signs of phytotoxicity. Each cherry was inspected for stem browning and for pitting. Cherries were considered to have browned stems if at least half the stem appeared shriveled and blackened, and to be pitted if the cherry surface was covered by small pits approximately $2 \mathrm{~mm}$ in diameter. Apricots, peaches, nectarines, pome, and citrus fruit were inspected for surface browning and streaking. Fruit were evaluated for decay by counting the number of decayed injuries and recording this value for each fruit. Analysis of variance was applied to the arcsine-transformed phytotoxicity and decay data with the GLM procedure (SAS Institute, Cary, NC). The least significant difference test was applied when the analysis of variance showed statistical significance $(P<0.05)$.

\section{RESULTS}

Cherries. Acetic, formic, and propionic acids significantly reduced decay in eight cherry cultivars inoculated with spores of M. fructicola, P. expansum, and R. stolonifer (Fig. 1). Examination of Selection $5 \mathrm{~J} 98$ white cherries inoculated with spores of $M$. fructicola showed that fumigation with acetic and formic acid completely prevented infection, because there was no sign of decay on these cherries (Fig. 2). Propionic acid was slightly less effective in preventing sporulation of $M$. fructicola in four of five inoculated cherries. Phytotoxicity, indicated by blackened stems and pitting of the fruit surface, occurred on fumigated cherries (Fig. 3). Formic acid increased blackened stems and tremendously increased pitting in fumigated cher- 
ries. Acetic acid was less damaging and caused only a slight increase in pitting. Propionic acid did not increase blackening of stems or pitting compared with the control. When individual cultivars were compared for susceptibility to pitting, fumigation with formic acid induced significantly more pitting on all cultivars except Sweetheart (Table 1). Pitting did not occur on Sweetheart even when it was fumigated with formic acid. Among cherries, acetic acid only increased pitting in Bing, while those fumigated with propionic acid did not have more pits than the control fruit. Lapin cherries were resistant to pitting by acetic and propionic acids but were severely pitted by formic acid. Van cherries were extremely susceptible to pitting, although even the control fruit were heavily pitted.

Stone fruit. Decay of apricots, peaches, and nectarines by $M$. fructicola was controlled by acetic and formic acids (Fig. 4). Formic and propionic acids controlled $R$. stolonifer, but acetic acid was ineffective on this pathogen. As found with cherries, formic acid was phytotoxic and led to severe streaking and browning of the epidermis on peaches, apricots, and nectarines (Fig. 3). Acetic acid also caused streaking and browning on stone fruit at these concentrations. Fumigation with propionic acid did not injure the fruit.

Pome fruit. Decay of pome fruit inoculated with spores of $P$. expansum was controlled by all three organic acids (Table 2). Formic and propionic acids were the most effective, reducing the number of injuries that decayed after fumigation from $98 \%$ to 4 and $8 \%$, respectively. Acetic acid at 2.5 $\mu \mathrm{l} /$ liter was less effective than formic acid but as effective as propionic acid at the same concentration, reducing decay to $16 \%$. None of the short-chain organic acid fumigants caused any apparent signs of phytotoxicity to any of the cultivars that were tested.

Citrus fruit. Decay of citrus fruit inoculated with spores of $P$. digitatum was effectively controlled by all three organic acids (Table 3). On grapefruit and oranges, decay did not develop on any of the wounds. Control appeared less effective on lemons, with many of the injuries decaying. Browning of the fruit epidermis occurred on some of the grapefruit and oranges fumigated with formic acid.
Lemons appeared to be more resistant to browning.

\section{DISCUSSION}

Fumigation with acetic, formic, and propionic acids prevented decay of cherries, stone fruit, pome, and citrus fruit by destroying spores of four different pathogens on the fruit surface. Previously, it was shown that vapor of acetic acid would kill spores of pathogenic fungi on the surface of fruit (17-19), but this is the first time it has been shown for formic and propionic acids. The concentrations of short-chain organic acids were selected based on known effectiveness of acetic acid (17) and relative strength of the acids. Interestingly, when calculations are made to determine the molar amount of each acid that was effective in killing fungal spores, all three acids were effective on most fruit at the same molar concentration of 33 to $34 \mu \mathrm{M}$.

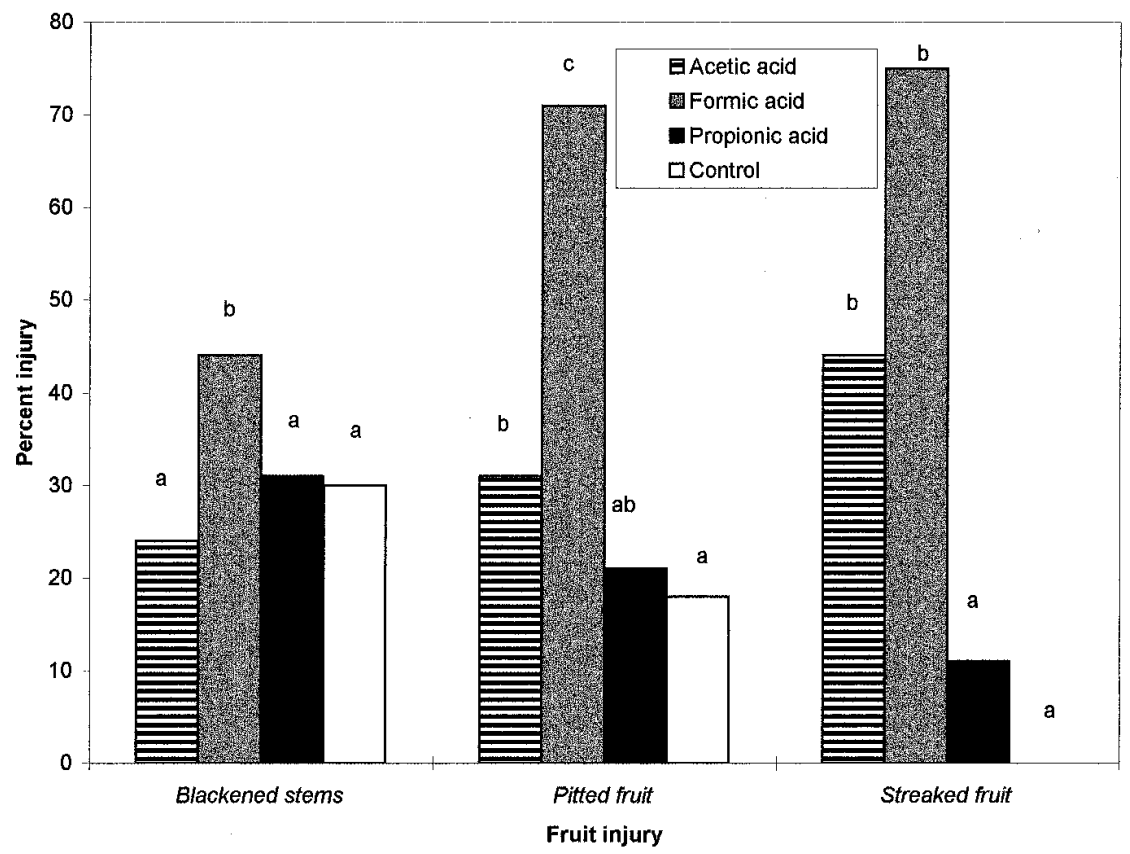

Fig. 3. Phytotoxicity due to fumigation with short-chain organic acids as measured by percent blackened stems, pitting, and streaking. Blackened stems and pitting were recorded on cherry, and streaking was recorded on apricots, peaches, and nectarines (stone fruit) fumigated with $1.3 \mu \mathrm{l}$ of formic acid, $1.9 \mu \mathrm{l}$ of acetic acid, or $2.5 \mu \mathrm{l}$ of propionic acid per liter. For each sign of phytotoxicity, different letters above bars indicate significant $(P \leq 0.05)$ differences among acids of arcsine-transformed data as determined by the least significant difference test.

Table 2. Percent pome fruit decayed after fumigation with formic, acetic, and propionic acids

\begin{tabular}{lcccc}
\hline & \multicolumn{3}{c}{ Concentration } & $\begin{array}{c}\text { Wounds decayed } \\
(\%)^{\mathbf{y}}\end{array}$ \\
\cline { 2 - 4 } Vapor & $\boldsymbol{\mu l} / \mathbf{l i t e r}$ & $\mathbf{m g} / \mathbf{l i t e r}$ & $\boldsymbol{\mu M} / \mathbf{l i t e r}$ & \\
\hline Control & 0.0 & 0.0 & 00 & $98 \mathrm{a}^{\mathbf{z}}$ \\
Formic & 1.3 & 1.6 & 34 & $4 \mathrm{c}$ \\
Acetic & 2.5 & 2.6 & 44 & $16 \mathrm{~b}$ \\
Propionic & 2.5 & 2.5 & 33 & $8 \mathrm{bc}$ \\
\hline
\end{tabular}

${ }^{y}$ Four fruit per chamber were fumigated for $30 \mathrm{~min}$ at $10^{\circ} \mathrm{C}$, aerated, and wounded with a glass rod ( $2 \mathrm{~mm}$ diameter) at four points on the fruit where spores had dried. Fumigations consisted of six apple cultivars (Golden Delicious, Granny Smith, Jonagold, Newtown, Red Delicious, and Spartan) and one pear cultivar (Anjou).

${ }^{\mathrm{z}}$ Means followed by the same letter within a row are not significantly different (LSD; $P \leq 0.05$ ).

Table 1. Percent cherries pitted after fumigation with formic, acetic, or propionic acid

\begin{tabular}{|c|c|c|c|c|c|c|c|c|}
\hline \multirow[b]{2}{*}{ Vapor $^{\mathbf{y}}$} & \multicolumn{8}{|c|}{ Cherry cultivar } \\
\hline & Bing & Lambert & Lapin & Stella & Sweetheart & Sylvia & Van & $5 J 98$ \\
\hline None & $7 a^{z}$ & $0 \mathrm{a}$ & $4 \mathrm{a}$ & $35 a$ & $0 \mathrm{a}$ & $9 \mathrm{a}$ & $66 \mathrm{a}$ & $24 \mathrm{a}$ \\
\hline Acetic & $42 \mathrm{~b}$ & $13 \mathrm{a}$ & $2 \mathrm{a}$ & $63 a$ & $0 \mathrm{a}$ & $13 \mathrm{a}$ & $77 \mathrm{a}$ & $38 \mathrm{a}$ \\
\hline Formic & $98 \mathrm{c}$ & $93 \mathrm{~b}$ & $60 \mathrm{~b}$ & $93 \mathrm{~b}$ & $0 \mathrm{a}$ & $62 \mathrm{~b}$ & $72 \mathrm{a}$ & $91 \mathrm{~b}$ \\
\hline Propionic & $26 \mathrm{a}$ & $2 \mathrm{a}$ & $2 \mathrm{a}$ & $47 \mathrm{a}$ & $0 \mathrm{a}$ & $11 \mathrm{a}$ & $76 \mathrm{a}$ & $4 \mathrm{a}$ \\
\hline SE (of a mean) & 2 & 3 & 3 & 2 & 2 & 3 & 1 & 3 \\
\hline
\end{tabular}

y Concentrations were $1.3,1.9$, and $2.5 \mu \mathrm{l}$ of liquid acid per liter of air for formic, acetic, and propionic acid, respectively.

${ }^{\mathrm{z}}$ Means followed by the same letter within a column are not significantly different (LSD; $P \leq 0.05$ ). 
This indicates that the same number of molecules of each short-chain organic acid is required to kill fungal spores when the acids are in the vapor state. Studies on thermophysical properties of acetic acid as a gas show that it consists of monomers and dimers at pressures below one atmosphere and that the components of the mixture are ideal gases (15).

Propionic acid was the most effective fumigant for cherries, causing no phytotoxicity and controlling $M$. fructicola, $P$. expansum, or $R$. stolonifer. Formic acid also prevented decay but caused excessive stem blackening and pitting of the fruit surface at half the concentration of propionic acid. Acetic acid was phytotoxic to one of eight cherry cultivars at a slightly lower concentration than propionic acid, making it useful as a fumigant for most cherries.

Propionic acid controlled $R$. stolonifer on apricots, peaches, and nectarines without any signs of phytotoxicity. Unfortu-

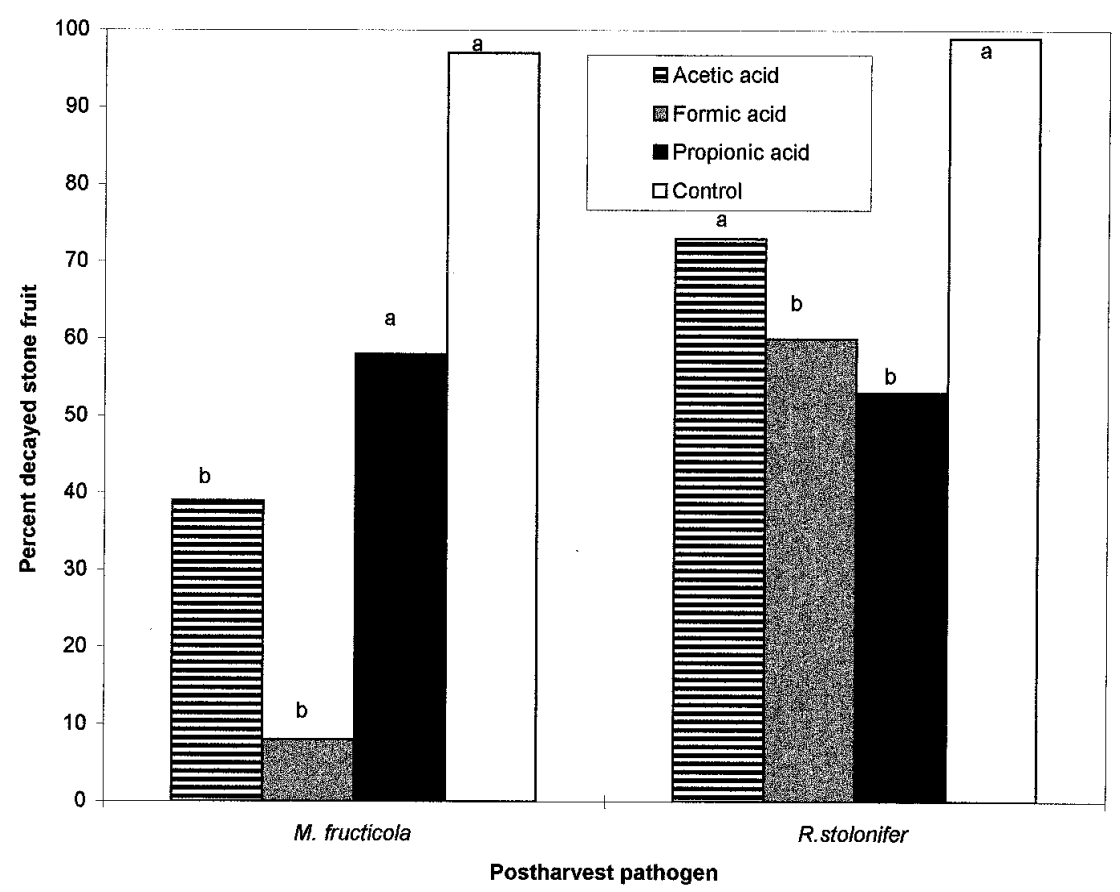

Fig. 4. Stone fruit (apricots, peaches, and nectarines) decayed after inoculation with $10^{6}$ conidia of Monilinia fructicola or Rhizopus stolonifer per liter and fumigation with $1.3 \mu \mathrm{l}$ of formic acid, $1.9 \mu \mathrm{l}$ of acetic acid, or $2.5 \mu \mathrm{l}$ of propionic acid per liter. For each postharvest pathogen, different letters above bars indicate significant (for $M$. fructicola, $P \leq 0.01$; for $R$. stolonifer, $P \leq 0.1$ ) differences among acids of arcsine-transformed data as determined by the least significant difference test.

Table 3. Percent citrus fruit decayed after fumigation with formic, acetic, and propionic acids

\begin{tabular}{lcccc}
\hline & \multicolumn{3}{c}{ Concentration } & Wounds decayed \\
\cline { 2 - 4 } Vapor & $\boldsymbol{\mu l} /$ /liter & $\mathbf{m g} / \mathbf{l i t e r}$ & $\boldsymbol{\mu} \mathbf{M} / \mathbf{l i t e r}$ & \\
\hline Control & 0.0 & 0.0 & 00 & $86 \mathrm{a}^{\mathbf{z}}$ \\
Formic & 1.3 & 1.6 & 34 & $11 \mathrm{~b}$ \\
Acetic & 1.9 & 2.0 & 33 & $11 \mathrm{~b}$ \\
Propionic & 2.5 & 2.5 & 33 & $11 \mathrm{~b}$ \\
\hline
\end{tabular}

${ }^{\text {y }}$ Four fruit per chamber were fumigated for $30 \mathrm{~min}$ at $10^{\circ} \mathrm{C}$, aerated, and wounded with a glass rod (2 $\mathrm{mm}$ diameter) at four points on the fruit where spores had dried. Fumigations consisted of three citrus cultivars (grapefruit, lemon, and orange) as replicates.

${ }^{\mathrm{z}}$ Means followed by the same letter within a row are not significantly different (LSD; $P \leq 0.05$ ).
When short-chain organic acids are used as fumigants, they are undissociated until they are absorbed into an aqueous medium such as the protoplasm of a living cell. The surface protection offered to epidermal cells by wax covering the pome fruit cuticle (7) must have protected them from injury by short-chain organic acid vapors, because pome fruit were not injured. However, epidermal cells of peaches and apricots must lack an effective protective cover, because they were burned by the low concentrations of formic and acetic acid used in this study. Skene (20) found that in stone fruit, specifically Ontario plum, the wax cover occurs as fibrils approximately $0.02 \mu \mathrm{m}$ thick and in small, thin platelets thinly scattered over the fruit surface, compared with apples, such as Cox's Orange Pippin, whose surface is covered by a thick layer of wax occurring as large, closely overlapping platelets ranging from 0.5 to $4 \mu \mathrm{m}$ across.

All three organic acids were extremely effective in controlling decay on citrus fruit caused by $P$. digitatum. However, control on lemons did not appear as good as on grapefruits or navel oranges and may have been due to prior infection by Penicillium spp. at the stem end. Some phytotoxicity of the citrus peel was observed with formic acid on grapefruit and navel oranges.

Because acetic, formic, and propionic acids are chemically closely related, they probably have the same mode of action on fungal spores. Acetic and propionic acids have been thoroughly reviewed as antimicrobial food preservatives and acidulants, and much information exists on their mode of action and spectrum of activity $(2,4-$ $6,8-10,14)$. Although traces of formic acid occur naturally in bananas, (3) and several microorganisms are known to produce it as a by-product (4), it is not used as a food preservative, and therefore little information is available on its antimicrobial properties. The mode of action of formic acid may be the same as that of acetic and propionic acids on fungal spores.

Early research demonstrated that the activity of short-chain organic acids was related to $\mathrm{pH}$, carbon chain length, and inherent susceptibility of the microorganism, and that the undissociated form of the acid was primarily responsible for its antimicrobial activity $(1,11,12)$. Formic acid has a shorter chain length than acetic and propionic acids, and thus it was expected that a lower concentration of formic acid would be needed for decay control. Evidence from this study supported this conclusion, because formic acid at a concentration of $1.3 \mu \mathrm{l} /$ liter was as effective as propionic or acetic acid at almost twice the concentration in killing spores of four decay-causing fungi. However, when this concentration is converted to micromolar amounts, the same number of micromoles of acetic and propionic are effective, indi- 
cating that as gases the number of molecules determines effectiveness of these acids.

In conclusion, this study has shown that acetic, formic, and propionic acids, when used in vapor form, are all very effective in destroying surface-borne fungal spores that cause decay. Each acid has particular strengths and weaknesses when applied for decay control. In general, formic acid is an exceptional sterilant and most ideally suited to destroying spores on walls and containers, but it should be kept away from most fresh produce because of its phytotoxicity. On the other hand, acetic and propionic acids are more suited for sterilizing fruit surfaces. Acetic acid is a better choice in most cases because it does not have an objectionable odor like propionic acid and has a long history of use on food. Thus, future use of these short-chain organic acids must be based on careful disease control trials in association with other methods of postharvest disease control that provide protection against infection.

\section{ACKNOWLEDGMENTS}

I thank Karen Bedford, Frank Mueller, Paula Haag, and Les Willis for excellent technical assistance, Frank Kappel, Rob Brownlee, and Richard MacDonald for the wide range of fruit samples, and John Hall for statistical assistance.

\section{LITERATURE CITED}

1. Creuss, W. V., and Irish, J. H. 1932. Further observations on the relation of $\mathrm{pH}$ value to toxicity of preservatives to microorganisms. J. Bacteriol. 23:163-166.

2. Davidson, P. M., and Juneja, V. K. 1990. Antimicrobial agents. Pages 83-137 in: Food Additives. A. L. Branen, P. M. Davidson, and S. Salminen, eds. Marcel Dekker, Inc., New York.

3. de la Teja, P. 1991. pH control agents. Pages 214-222 in: Food Additive User's Handbook. J. Smith, ed. Von Nostrand Reinhold, New York.

4. Dillon, V. M., and Cook, P. E. 1994. Biocontrol of undesirable microorganisms in food. Pages 255-296 in: Natural Antimicrobial Systems and Food Preservation. V. M. Dillon and R. G. Board, eds. CAB International, Wallingford, Okon, Eng.

5. Doores, S. 1990. pH control agents and acidulants. Pages 477-510 in: Food Additives. A. L. Branen, P. M. Davidson, and S. Salminen, eds. Marcel Dekker, Inc., New York.

6. Doores, S. 1993. Organic acids. Pages 95-136 in: Antimicrobials in Foods. P. M. Davidson and A. L. Branen, eds. Marcel Dekker, Inc., New York.

7. Esau, K. 1977. Anatomy of Seed Plants. John Wiley \& Sons, New York.

8. Freese, E., Sheu, G. W., and Galliers, E. 1973. Function of lipophilic acids as antimicrobial food additives. Nature 241:321-325.

9. Gardner, W. H. 1981. Acidulants in food processing. Pages 225-270 in: CRC Handbook of Food Additives. T. E. Furia, ed. CRC Press, Inc., Boca Raton, FL.

10. Gould, G. W., Brown, M. H., and Fletcher, B. C. 1983. Mechanisms of action of food preservation procedures. Pages 67-84 in: Food Microbiology: Advances and Prospects. T. A. Roberts and F. A. Skinner, eds. Academic Press, London.

11. Hoffman, C., Schweitzer, T. R., and Dalby, G.
1939. Fungistatic properties of the fatty acids and possible biochemical significance. Food Res. 4:539-545.

12. Levine, A. S., and Fellers, C. R. 1940. Action of acetic acid on food spoilage microorganisms. J. Bacteriol. 39:499-514.

13. Moyls, A. L., Sholberg, P. L., and Gaunce, A. P. 1996. Modified-atmosphere packaging of grapes and strawberries fumigated with acetic acid. HortScience 31:414-416.

14. Reynolds, A. E., Jr. 1975. The mode of action of acetic acid on bacteria. Diss. Abstr. B35:4935-4936. Ph.D. thesis. University of Georgia, Athens.

15. Seaton, W. H. 1993. Acetic acid. Pages 73100 in: Acetic Acid and its Derivatives. V. H. Agreda and J. R. Zoeller, eds. Marcel Dekker, Inc., New York.

16. Sholberg, P. 1996. Fumigation of fruit with organic acids to prevent postharvest decay. (Abstr.) Phytopathology 86:S70.

17. Sholberg, P. L., and Gaunce, A. P. 1995. Fumigation of fruit with acetic acid to prevent postharvest decay. HortScience 30:12711275.

18. Sholberg, P. L., and Gaunce, A. P. 1996. Fumigation of stone fruit with acetic acid to control postharvest decay. Crop Prot. 15:681686.

19. Sholberg, P. L., Reynolds, A. G., and Gaunce, A. P. 1996. Fumigation of table grapes with acetic acid to prevent postharvest decay. Plant Dis. 80:1425-1428.

20. Skene, D. S. 1963. The fine structure of apple, pear, and plum fruit surfaces, their changes during ripening, and their response to polishing. Ann. Bot. 27:581-587.

21. Wagner, M. K., and Moberg, L. J. 1989. Present and future use of traditional microbials. Food Technol. 43:143-147. 